\title{
Sustainable development goals and the scientific community: a systematic review of the literature and the research agenda
}

\author{
Os objetivos de desenvolvimento sustentável e a comunidade científica: uma revisão sistemática da
}

literatura e da agenda de pesquisa

Los objetivos de desarrollo sostenible y la comunidad científica: una revisión sistemática de la literatura y la agenda de investigación

\begin{abstract}
The aim of this paper is to discuss the process of the constitution of the Sustainable Development Goals and, by extension, present how the scientific community has been collaborating with its legitimization and adoption. Specifically, we will explore and contextualize the 2030 Agenda and its relationship with the scientific community, presenting an overview of the field, as well as providing recommendations and directions for future research. Methodologically, the manuscript shares an exploratory approach and is carried out through bibliographic reviews and bibliometric analysis. The main results found are: most of the published studies analyzed originate from NorthGlobal countries; there has been a quantitative growth regarding the number of publications made in the period consulted, especially between the years 2019-2021; regarding the types of studies identified, case studies on experiences implemented in the university environment stand out, as well as studies that address the social commitment of this community in relation to the SDGs; as for research collaboration, there is a predominance among countries of the Global North, with sporadic collaborations between countries of the Global North-South and the Global South-South.
\end{abstract}

Keywords: Sustainable development goals; Scientific community; Research agenda; Bibliometric analysis; VOSviewer.

\section{Resumo}

O objetivo deste artigo consiste em discutir o processo de constituição dos Objetivos de Desenvolvimento Sustentável e, por extensão, apresentar como a comunidade científica vem colaborando com sua legitimação e adoção. Especificamente, vamos explorar e contextualizar a Agenda 2030 e sua relação com a comunidade científica, apresentando uma visão geral do campo, bem como fornecer recomendações e orientações para pesquisas futuras. Metodologicamente, o artigo compartilha uma abordagem exploratória e é realizado através de revisões bibliográficas e análises bibliométricas. Os principais resultados encontrados são: a maioria dos estudos publicados analisados tem origem em países do Norte-Global; houve um crescimento quantitativo no número de publicações realizadas no período consultado, especialmente entre os anos 2019-2021; quanto aos tipos de estudos identificados, destacam-se estudos de caso sobre experiências implementadas no ambiente universitário, bem como estudos que abordam o compromisso social desta comunidade em relação aos ODS; quanto à colaboração em pesquisa, há uma predominância entre países do Norte Global, com colaborações esporádicas entre países do Norte Global-Sul e do Sul Global Sul-Sul.

Palavras-chave: Objetivos de desenvolvimento sustentável; Comunidade científica; Agenda de pesquisa; Análise bibliométrica; VOSviewer.

\section{Resumen}

El objetivo de este trabajo es discutir el proceso de constitución de los Objetivos de Desarrollo Sostenible y, por extensión, presentar cómo la comunidad científica ha colaborado con su legitimación y adopción. Específicamente, exploraremos y contextualizaremos la Agenda 2030 y su relación con la comunidad científica, presentando una 
visión general del campo, así como proporcionando recomendaciones y direcciones para futuras investigaciones. Metodológicamente, el manuscrito comparte un enfoque exploratorio y se lleva a cabo mediante revisiones bibliográficas y análisis bibliométricos. Los principales resultados encontrados son: la mayoría de los estudios publicados analizados proceden de países del Norte-Global; se ha producido un crecimiento cuantitativo en cuanto al número de publicaciones realizadas en el periodo consultado, especialmente entre los años 2019-2021; en cuanto a los tipos de estudios identificados, destacan los estudios de caso sobre experiencias implementadas en el ámbito universitario, así como los estudios que abordan el compromiso social de esta comunidad en relación con los ODS; en cuanto a la colaboración en investigación, predomina entre los países del Norte Global, con colaboraciones esporádicas entre países del Norte-Sur Global y del Sur-Sur Global.

Palabras clave: Objetivos de desarrollo sostenible; Comunidad científica; Agenda de investigación; Análisis bibliométrico; VOSviewer.

\section{Introduction}

The 17 Sustainable Development Goals (SDGs), launched in 2015 by the heads of State of the United Nations, incorporate a series of issues related to the social, economic, and environmental dimensions of sustainable development. It is a global development agenda that requires the involvement of various actors so that its implementation and materialization can be achieved by 2030 . Therefore, as it is a science-based agenda, the SDGs require the performance of the scientific community in general, to produce knowledge about the SDGs.

In this sense, the aim of this paper is to discuss the process of the constitution of the Sustainable Development Goals and, by extension, present how the scientific community has been collaborating with its legitimization and adoption. Specifically, the authors explore and contextualize the 2030 Agenda and its relationship with the scientific community, presenting an overview of the field, as well as providing recommendations and directions for future research. The questions that underlie this manuscript are: in what way the SDG agenda was constituted? in normative terms, how can the scientific community collaborate with the implementation and legitimation of the SDGs? in terms of scientific production, what is the status of research on SDGs? what are the main topics of interest for this community and what research questions can be provided for future research?

Methodologically, sharing an exploratory approach, the manuscript is carried out through bibliographic review activities, in addition to conducting a bibliometric analysis of the scientific productions that address the SDGs, Higher Education Institutions, funding agencies and the research community in general. As a form of organization, the article is divided into three sections, in addition to this introduction and final considerations. The first section aims to present the history of the constitution of the 17 SDGs, in addition to discussing how the scientific community is required to act to achieve them. The second section presents the methodological procedures carried out in the mapping activities and bibliometric analysis. Finally, the last section aims to present and analyze the results obtained through the bibliometric analysis.

\section{SDGs and the Scientific Community}

The concept of "sustainable development" emerged in 1987 through the discussions held by the World Commission on Environment and Development, through the publication of the Brundtland Report (or "Our Common Future"), considering it as the one "that meets the needs of the present without compromising the ability of future generations to meet their own needs" (Brundtland Report, 1987, p. 41).

For this concept to be formulated and validated at the international level, a series of events related to the perception of the environmental crisis took place, going a long way to the emergence of the Sustainable Development Goals (SDGs). Although we do not aim to trace a history of this process, we highlight some episodes that mark the origin of this idea: the first refers to the initial perceptions of the scientific community about a global environmental risk marked by nuclear pollution, especially during the 1950s (Machado, 2005; Do Nascimento, 2012); the second moment refers to the publication of the book 
"Silent Spring" by biologist Rachel Carson in 1962, which denounces the environmental crisis caused using pesticides and chemical insecticides in the United States; the third moment refers to the approval and realization of the Stockholm Conference in 1972, which sought to reconcile the growth of economic activities with environmental preservation (Nascimento, 2012); finally, still in 1972, we can highlight the publication of the Report of the Club of Rome - Limits to Growth, which suggested a process of "slowing down industrial development in developed countries and population growth in underdeveloped countries" (Nascimento, 2012, p. 53, own translation; Meadows et al., 1972).

Such historical events mark the mobilization of different actors (governmental and non-governmental) in relation to the growing concerns with the environmental issue, in view of the warnings concerning the dependence on natural resources, as well as the existing possibilities in relation to their depletion. The Brundtland Report, therefore, being the first major effort to reconcile economic growth and environmental preservation, made the definition of the term "sustainable development" classic, suggesting its recognition as a guiding axis for international economic and political activities (Nascimento, 2012; Vizeu et al., 2012). It is, therefore, a definition that has become the subject of major debates at the international level, both positively and negatively, considering the critical perspectives that analyze its conception (Scoones, 2010).

Besides the events mentioned above, we highlight the United Nations Conference on Environment and Development in 1992, popularly known as "Rio-92" or "ECO-92", with the participation of representatives from 172 countries. Taking place 20 years after the first Stockholm Conference, ECO-92 resulted in the creation of the Convention on Biodiversity and Climate Change (which led to the Kyoto Protocol), the Rio Declaration on Environment and Development, and Agenda 21 (United Nations, 1992).

Specifically on Agenda 21, it is configured as a planning instrument or action program aimed at achieving changes for a new development model for the 21 st century, based on "sustainable development". It is, therefore, a document consisting of 40 chapters, which seek to guide governmental (and, by extension, non-governmental) actions through priority themes (such as deforestation, waste, climate, soil, water, biotechnology, among others), considering bases for action, objectives, activities and means of implementation (United Nations, 1992).

It was only in September 2000 that the heads of state of the United Nations gathered at their headquarters to adopt the UN Millennium Declaration, also known as the Millennium Development Goals (MDGs). It was through these goals that the nations committed themselves to a new global development agenda, based on a series of eight goals to be achieved by 2015 . The MDGs had as their main objective to combat extreme poverty, as well as to provide universal primary education, especially in the contexts of countries considered to be developing (mostly countries of the Global South).

Despite being a global agenda, the MDGs were focused on low- and middle-income country settings, not contemplating goals that applied to all nations. In this sense, because it is a limited agenda, it did not gain full notoriety by developed countries (Mibielli and Barcellos, 2014). Nevertheless, it achieved positive and significant results in certain contexts, as in the Brazilian case (Fernandes et al., 2015; Marinho et al., 2020).

In view of the discussions regarding the continuity of the sustainable development agenda at the global level, as well as considering the debates concerning the concept itself, we can check its emergence as a predominant framework as of the "Rio+20" Conference in June 2012, which creates the task of developing the Sustainable Development Goals (SDGs) (Caballero, 2019).

According to Fukuda-Parr and Muchhala (2020), although the SDGs emerged out of a narrative that encompassed the MDG agenda, the SDGs were also created to transcend its limitations. In this sense, in addition to continuing the MDG agenda with some modifications (MDG+), the SDGs also incorporate a broader and more ambitious vision for addressing problems related to poverty, inequality, violence, climate change, among others.

Their creation and development process derives from the Rio+20 Conference, mentioned above. On this occasion, an 
individual delegate from Colombia, Paula Caballero Gómez, proposed the idea of developing the SDGs. Then, from resolution 66/288 - The future we want, of July 27, 2012, the UN General Assembly, together with the heads of state, decides to continue the global development agenda, with a view to establishing an Open Working Group (OWG) that would oversee constituting a proposal for the consideration of the Sustainable Development Goals.

It was, therefore, a differentiated process in relation to the development of the MDGs. In this sense, when analyzing the documents about its development, it is possible to observe the following: a total of 30 members participated in the OWG, representing their countries and regions; the members of the OWG elected as Co-chairs Csaba Körösi (representative of Hungary) and Macharia Kamau (representative of Kenya); iii. The OWG process and timeline followed the following steps: "1. Election of officers; 2. Adoption of the agenda and other organizational matters; 3. Follow-up to the outcome of the United Nations Conference on Sustainable Development, relating to a proposal for sustainable development goals; 4 . Other matters; 5. Adoption of the report"; 13 sessions were held to discuss and create the SDGs between 2013 and 2014; among the 13 sessions, 8 were held to discuss topics considered relevant to the OWG members (with the participation of other members and stakeholders through thematic clusters); From these sessions, the SDGs were discussed and negotiated, being informally presented through an early version on December 4, 2014, by UN Secretary-General Ban Ki-moon to UN member states; vi. officially, the SDGs were approved and adopted on September 25, 2015, during the United Nations Summit on Sustainable Development in New York (United Nations, 2014, p. 4).

Since their approval, the SDGs have been in force from 2016 to 2030, constituting a global agenda that seeks to guide both the political action of Heads of State and the actions and activities developed by other actors in civil society (such as public and private companies, the scientific community, non-governmental organizations, civil society associations, as well as the behavior of the population in general). It is important to emphasize, however, that such an agenda does not make it obligatory for a country, state, or other stakeholders to adopt and comply with it. It is, in fact, an optional commitment of an ethical, political, and diplomatic nature.

The SDGs, with the motto "leave no one behind", are organized into 17 goals, containing a total of 169 targets to be met by 2030. As a form of organization, we can consider that they are distributed through four dimensions: social, environmental, economic, and institutional, interconnected among themselves. The social dimension incorporates the SDGs related to poverty eradication (SDG 1), zero hunger and sustainable agriculture (SDG 2), health and well-being (SDG 3), quality education (SDG 4), gender equality (SDG 5), and reduction of inequalities (SDG 10). The environmental dimension is about clean water and sanitation (SDG 6), clean and affordable energy (SDG 7), responsible consumption and production (SDG 12), action against global climate change (SDG 13), life on water (SDG 14), and terrestrial life (SDG 15). Within the economic dimension, the SDGs related to decent work and economic growth (SDG 8), industry, innovation, and infrastructure (SDG 9) and sustainable cities and communities (SDG 11) are highlighted. Finally, regarding the institutional dimension, we consider the SDGs related to peace, justice, and effective institutions (SDG 16) and partnerships and means of implementation (SDG 17).

As a way of monitoring and evaluating, the SDGs have a set of 231 indicators, distributed in relation to the goals that comprise them, providing clearer guidelines regarding the means of implementation (such as the need for mobilizing financial resources, developing capacities, and establishing partnerships between different actors, the role of technology and its dissemination among nations, as well as the institutional development of such goals and targets).

Despite having been developed differently from the MDGs, as well as sharing a more holistic approach to the main issues to be addressed by the international community, some criticisms can be attributed to the agenda, as well as to the concept of "sustainable development" itself. Specifically in relation to the SDGs, we can observe from the literature that there are positive expectations in relation to their achievement (especially related to the elimination of preventable deaths among 
newborns and children under 5 years old, as well as the access of children to primary education). However, the SDGs fall short in critical areas, such as those related to poverty, agricultural production and environmental sustainability, climate protection, and biodiversity loss. The main reasons are lack of funding, lack of data on some indicators, the consequences generated by the Covid-19 pandemic, as well as disagreement between some SDGs (for example, the balance between GDP growth and its impact on climate).

Regarding the term "sustainable development," the literature presents a vast number of studies that address its contradiction (Ratiu and Anderson, 2014; Hickel, 2015; Sankowski and Harris, 2018; Ferraro Junior, 2016). We highlight, therefore, the perspective of Vizeu et al. (2012) that, by glimpsing its ideological essence, argues about the existence of a false understanding about the harmony between the ecological issue and the capitalist system. The study by Freitas et al. (2012) also corroborates this view, problematizing the productive relations alienated from nature, in force in the current model of capitalist production. In other words, the issue of "catopardism" must also be highlighted since it aims to cause socioeconomic and environmental changes without changing the current economic system. Supporting these ideas, we can say that, despite proposing a transformation in certain areas, the SDGs do not propose a structural change in the system, since they attribute the achievement of the goals to global economic growth.

The strong criticisms of the above authors further reinforce the argument that the SDG agenda refers to a hegemonic agenda, adopting the existing problems as universal, as well as "erasing" the power relations present in the international arena, especially between the countries of the Global North and South. There is, therefore, an idea that if everyone cooperates, we can solve the problems indicated on the international agenda.

Despite those criticisms, this agenda has become mandatory in certain contexts, as is the case of access to sources of funding for research abroad, especially in European countries. The Horizon 2020 program of the European Commission, for example, is based on the SDGs framework, with a mandatory requirement to mention the SDGs in proposals submitted to certain calls (European Commission, 2021).

Specifically on the scientific community (considering HEIs, research funding agencies, centers, and research laboratories), the SDGs demand a performance focused on the production and dissemination of knowledge and technologies, considering the narratives related to the concepts "mission-oriented Science", "mission-driven research", "knowledge-based transformation" and "action agenda for Science".

Such demands make the scientific community as one of the main actors responsible for the legitimization, implementation, and achievement of the SDGs, with several studies and documents dealing with this commitment (Leal Filho et al., 2021). Considering such studies, we can highlight that the scientific community has been mobilizing regarding its adoption through the actions of international scientific associations (Dibbern and Serafim, 2021), as well as through activities within HEIs and development agencies (ISC, 2020; 2021).

In a normative way, that is, as a form of collaboration in relation to what this community must accomplish, the studies deal with the performance of HEIs through the performance of teaching and research activities, as well as activities and actions aimed at community engagement (and, complementarily, university extension practices) and internal management of the institutions. As far as teaching is concerned, this is mainly focused on issues related to the adoption of Education for Sustainable Development as one of the subjects that must be offered to students/university students (Disterheft et al., 2013; ISCN, 2018; UNESCO, 2017; GUNi, 2019).

In terms of conducting research, there is demand for advancing knowledge in individual disciplines (such as those related to health, demography, governance, digitalization, and urbanization), as well as conducting interdisciplinary research to integrate knowledge generated in a disciplinary manner, with a view to creating new knowledge (Ruiz-Mallén and Heras, 2020; GUNi, 2019). Among the areas indicated in the report "Transformations to achieve the Sustainable Development Goals 
(IIASA, 2018), researchers from around the world have been researching on the existing links between poverty, hunger, and health; health, sanitation, and inequalities; poverty and climate. Research is also encouraged around issues concerning the "effects of poverty on health and economy, of education on inequalities, renewables on cities, climate mitigation on the oceans, and of cities on water, economy, governance and infrastructure" (IIASA, 2018, p. 100).

Regarding the dimension of community engagement and university extension, we can observe studies that deal with the social commitment of these institutions in relation to their external community, considering the local, regional, national, and international context (GUNi, 2019; Macedo et al., 2019). In terms of management and governance, the literature presents the adoption of the SDGs as a strategic policy to be incorporated by these institutions, enabling the establishment of cooperation's and partnerships among various actors (GUNi, 2019; ISC, 2020).

In general, we can say that in the scope of HEIs, contributions are expected in terms of: mobilization of existing knowledge, as well as generation and dissemination of new knowledge and technologies; integration of disciplines through the adoption of an interdisciplinary approach, in addition to the adoption of the premises related to Education for Sustainable Development in the teaching curriculum of higher education courses; establishment of cooperation and partnerships among universities, government, companies, and civil society; construction of networks among experts and policymakers, aiming at the implementation of political actions guided by scientific knowledge; and, scientific communication, considering the dissemination of scientific knowledge to the lay community.

Regarding the research funding agencies, they are asked to do the following: given the full potential of science in support of the SDGs, collaborative approaches to research funding are essential, "moving away from individual to collective action. Together, science funders are in a powerful position and can achieve a longer-term impact at a scale beyond what any one actor could achieve alone" (ISC, 2020, p. 3). Therefore, to accelerate the implementation of the SDGs, several research funding agencies joined the discussions promoted by the ISC to address issues such as the potential and responsibility of funding agencies, the impact of investments in science related to the SDGs, building networks and collaborative research alliances for the SDGs. In these opportunities, the "Decade of Global Sustainability Science Action (2020-2030)" was launched through the events of the Global Forum of Funders between the years 2019 and 2020 (ISC, 2020).

In other words, we can list the forms of contribution of this community from five categories (Figure 1).

Figure 1. Contributions of the scientific community to the SDGs.

\section{Knowledge production}

-All areas of knowledge

\section{Expertise}

-Scientist/researcher's performance in the elaboration of public policies

\section{Communication}

-Scientific communication and dissemination

\section{Education}

-Incorporation of the SDGs in teaching curricula

5. Institutional action of HEIs and funding agencies

-Incorporation of the SDGs in the strategic objectives of institutions, research agendas and financing lines 
Therefore, considering the roles assigned by the SDG agenda to the scientific community in general, in the next sections of this manuscript we present a bibliometric review of what the scientific community has been doing in the field of knowledge production about the SDGs.

\section{Methodological Procedures}

The methodological procedures used in this article are based, above all, on bibliographic review and bibliometric analysis. Regarding bibliometric analysis, it is important to highlight that this refers to a method that has gained greater popularity in recent years, since it enables the exploration and analysis of a large volume of scientific publication data on certain topics and areas of knowledge (Ellegaard and Wallin, 2015; Donthu et al., 2021).

That said, the first step in this research consisted of conducting a bibliometric survey of the literature related to the Sustainable Development Goals (SDGs) and their relationship with the scientific community, considering the activities developed within Higher Education Institutions (HEIs), universities, research centers and laboratories. Secondly, to perform the bibliometric analysis, we used as database the Web of Science (WoS) platform, by using the following keywords: ("higher education" OR "university" OR "scientific community" OR "research community" OR "academic community") AND ("SDGs" OR "global goals" OR "2030 agenda" OR "sustainable development goals" OR "Post-2015 Development Agenda"), as topics (considering title, keywords and abstract). This search obtained a total of 845 results, including 654 articles, 125 conference papers (scientific events), 48 early access articles, 37 review articles, 31 editorial materials, 1 letter, and 1 meeting abstract (Figure 2). The search was conducted on September 30, 2021, and a temporal filter was established for publications made between 2015 and the date of the documentary search.

Figure 2. Bibliometric analysis design.

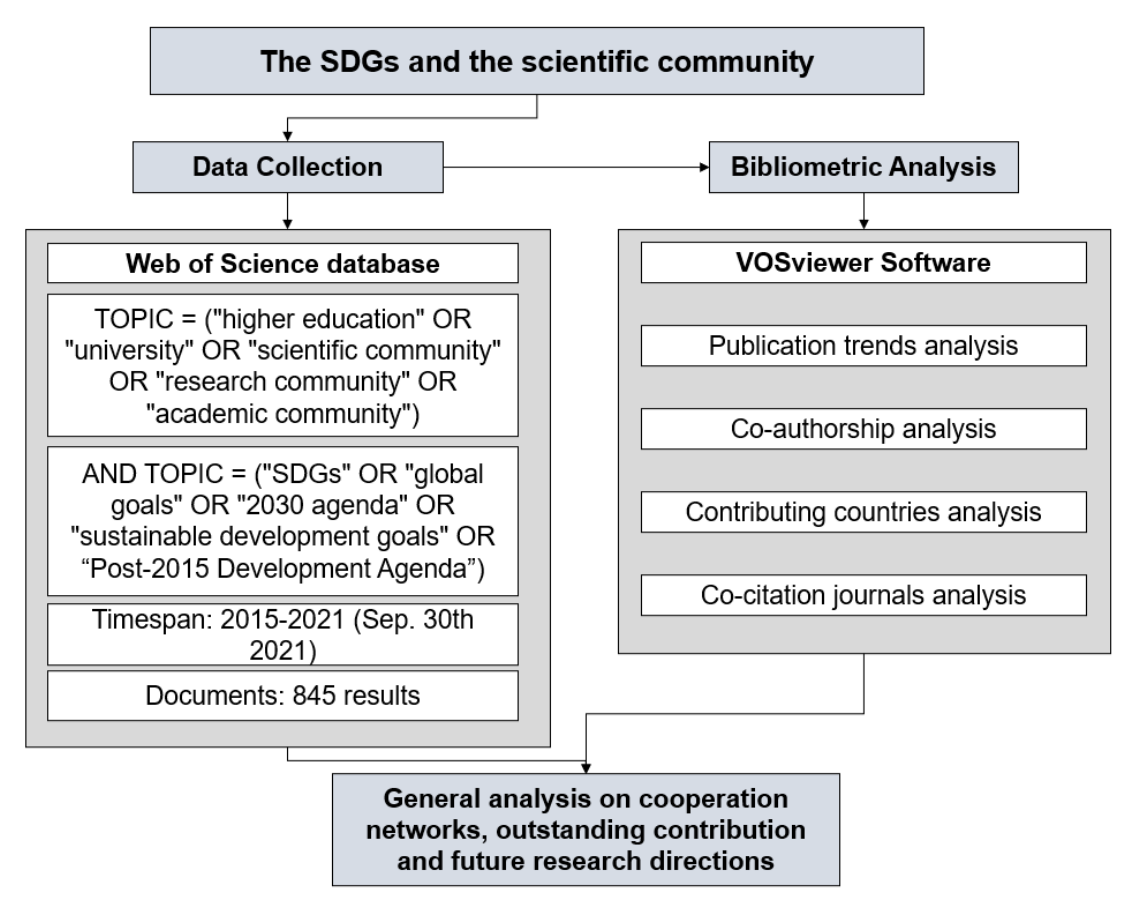

Source: Authors.

As for performing the analysis, we considered the following types of documents: articles, conference papers, advance articles, and review articles (total of 812 results) and, for a valid result for the bibliometric analysis, we filtered the studies that 
did not match the proposed theme (considering the title, abstract, and keywords of each study), resulting in a total of 641 studies for performing the analysis. In addition to using the Web of Science Platform, we applied the VOSviewer software, in view of the possibility of presenting visualization networks of the content addressed. In the words of Xia et al. (2021), the "VOSviewer is an optimal approach to analyzing the correlation of highly cited publications with productive authors", and can be used to build maps of authors, journals, keywords, considering data regarding co-citation and co-occurrence. In addition, the software classifies keywords into different clusters, considering the results of co-occurrence and frequency analysis (Xia et al., 2021).

\section{Results and Discussion}

The results obtained through the bibliometric analysis conducted via WoS, show a significant growth in relation to the number of publications over the years (from 2015 to September/2021) in relation to scientific production on the SDGs and the scientific community in general. In this sense, from Figure 3, we can highlight the years 2019, 2020 and 2021 , which hold a greater number of published articles on the topic.

Figure 3. Publication Year related to SDGs and the scientific community (2015-September/2021).

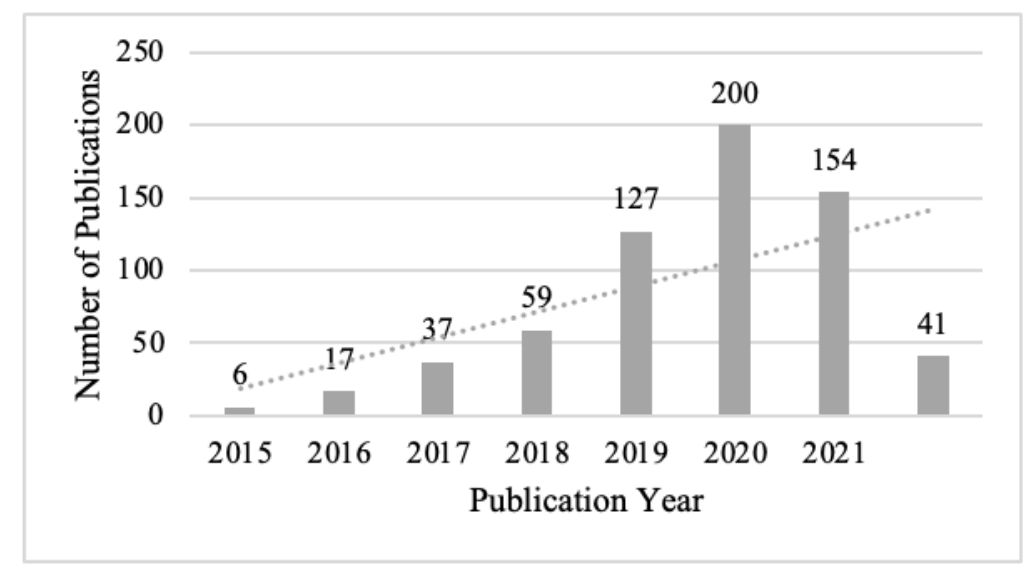

Source: Authors.

Regarding the Journals that have the largest number of published articles on the topic, "Sustainability", "International Journal of Sustainability in Higher Education" and the "Journal of Cleaner Production" stand out. Table 1 displays the total number of publications from the top 10 journals publishing on the topic. However, it should be noted that the Web of Science platform is limited by not indexing all existing journals in its database and, therefore, presents results from journals that mostly publish articles in English, not covering all publications indexed in other databases (such as Scopus, Scielo, Google Scholar, among others). 
Table 1. Top 10 productive mainstream Journals in SDGs and the scientific community (2015-September/2021)

\begin{tabular}{|c|l|c|}
\hline$\#$ & Journal & Count \\
\hline 1 & Sustainability & 149 \\
\hline 2 & International Journal of Sustainability in Higher Education & 61 \\
\hline 3 & Journal of Cleaner Production & 13 \\
\hline 4 & International Journal of Management Education & 11 \\
\hline 5 & International Journal of Environmental Research and Public Health & 10 \\
\hline 6 & Higher Education & 9 \\
\hline 7 & European Journal of Sustainable Development & 8 \\
\hline 8 & Education Sciences & 8 \\
\hline 9 & Journal of Chemical Education & 5 \\
\hline 10 & Revista Universidad y Sociedad & 4 \\
\hline
\end{tabular}

Source: Authors.

Considering the analysis performed via VOSviewer software and, considering that the minimum number of occurrences per term was 6 , we will now present the co-occurrence word networks generated through the sample obtained via WoS. The result of this analysis can be seen in Figure 4, showing the terms "SDGs" and "higher education".

Figure 4. Co-occurrence network related to SDGs and the scientific community.

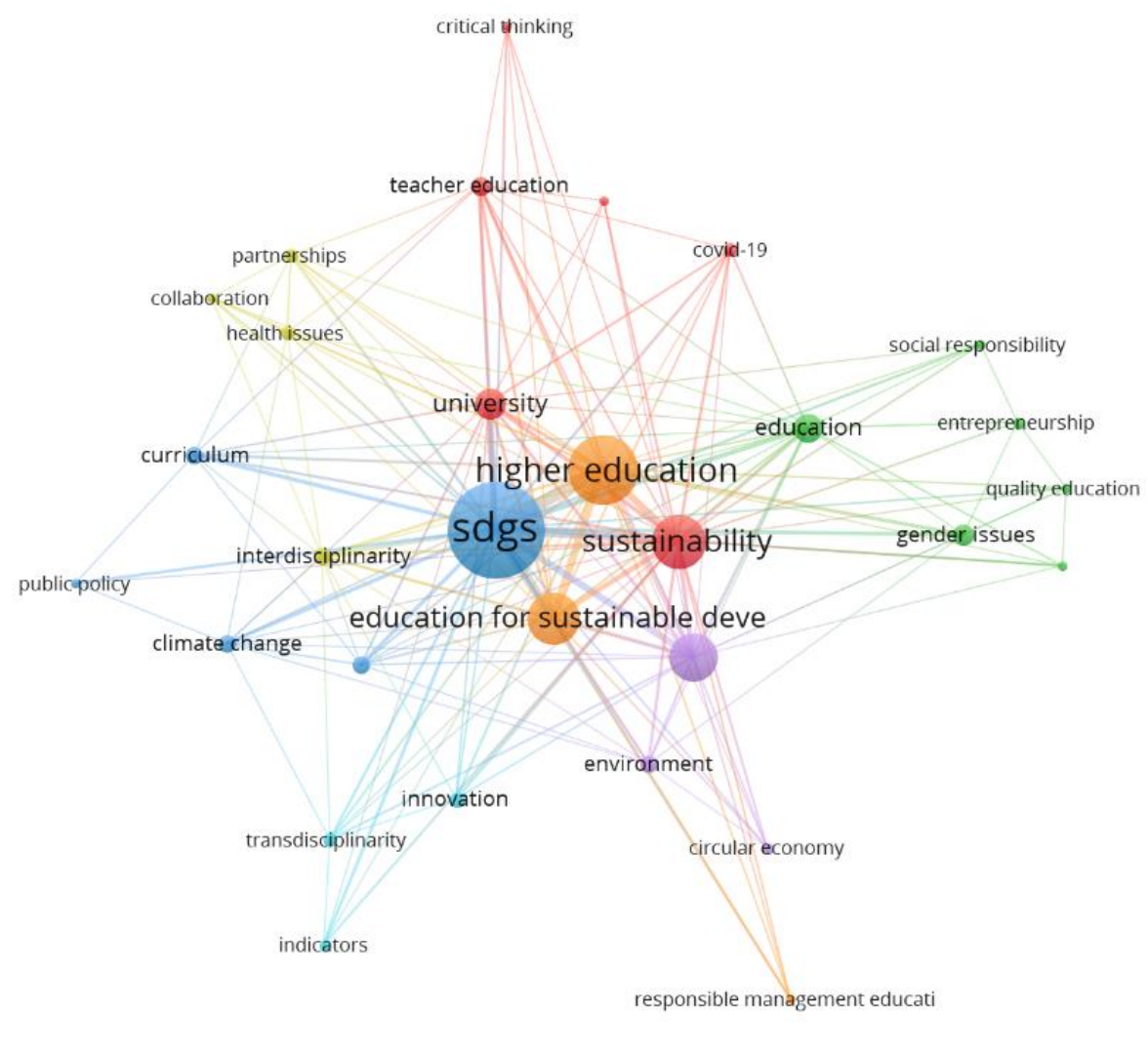

Source: Data generated from VOSviewer.

From this figure it is possible to note the following: cluster 1 (red) presents the most frequent publication topics in 
relation to the SDGs and the scientific community. As can be seen, the terms "sustainability," "university," "teacher education," "inclusion," and "covid-19" are most prominent. Among the studies that address these themes, we can mention AlJaber and Al-Ghamdi (2020), which analyze the impact of remote education in times of the Covid-19 pandemic in Qatar, in relation to the quality of education (SDG 4); Garcia-Rico et al. (2021), which addresses the pedagogical model of teaching programs for physical education teachers in view of the SDGs; and, Weber et al. (2021) which provides an outline of an interdisciplinary training workshop on the SDGs to be implemented within higher education.

The remaining clusters expose publication topics that are emerging in the literature, i.e., have been gaining greater notoriety by the academic community in recent years. Cluster 2 (green) aggregates the topics related to "education", "gender issues", "social responsibility", "entrepeneurship", "quality education", and "engineering". As an example, we can cite the studies by Fabrega et al. (2020), which analyzes the relationship between business and entrepreneurial skills and environmental commitment as sources of mobilization and action of university students toward sustainable development; as well as the study by Reverter (2020), which addresses the issue of gender equality in the university environment.

Cluster 3 (blue) highlights the studies related to the "SDGs", "climate change", "curriculum", "public policy", and "university students". Among these, Perkins et. al (2018) makes its contribution through its study on Education for Sustainability and the social context of climate change, considering data from interviews conducted with academics from several countries. Other studies can also be highlighted, as is the case of the paper produced by Salvia et. al (2020), which analyzes energy sustainability in the scope of university education, and Leal Filho et al. (2021), which seeks to bridge the gap in the literature regarding the inclusion of SDGs at the university level, in view of teaching and research activities.

Cluster 4 (yellow) emphasizes the studies that deal with the establishment of "collaborations" and "partnerships", as well as those that deal with the "interdisciplinary" approach and "health issues". As a highlight, Kuo et al. (2020) analyzes the role of community culture in food product innovation courses considering the SDG agenda. Regarding the interdisciplinary approach, this can be found in the studies by Broo et al. (2021) and Ruiz et al. (2019). As for studies on establishing collaborations and partnerships, we can highlight the papers by Sugandhar and Chaudhary (2017) and Moon et al. (2018).

Cluster 5 (purple) indicates the topics "sustainable development", "environment" and "circular economy", and the studies produced by Owojori et al. (2020) and Gonzalez-Dominguez et al. (2020) can be highlighted. Cluster 6 (light blue) highlights studies on "innovation," "transdisciplinarity," and the development of "indicators," such as those produced by Maruyama et al. (2020), and Leal Filho et al. (2019). Finally, cluster 7 (orange) pervades over the topics of "higher education," "education for sustainable development," and "responsible management education," such as the studies by FernandezIzquierdo et al. (2017) and Avelar et al. (2019).

It was possible to noticed that in 2019, the most prominent sub-themes centered on discussions about establishing collaborations, partnerships, data, and indicator generation, as well as governmental issues, related to public policy and health issues. The dimensions of education for sustainable development, interdisciplinarity and transdisciplinarity, and quality of education were also in vogue. And, as of late 2019 and early 2020, the research agenda began to incorporate other issues, particularly on the Covid-19 pandemic, gender and inclusion issues, climate change, curriculum, social responsibility, innovation, environment, and circular economy.

A total of 2,111 authors and co-authors were identified through the analysis performed. Regarding the origin of the verified productions, we could identify a total of 107 countries involved in the production of knowledge. Figure 5 exposes the 24 countries that present the greatest number of studies produced on the topic, highlighting the red, green, and blue clusters. Thus, it is notable a higher rate of articles produced in countries of the Global North, especially Spain, England, Germany, and the United States. We should also highlight the countries of the Global South that also stand out in relation to the production of knowledge on SDGs and the scientific community: Brazil and South Africa. It is noteworthy again that the data obtained 
through the WoS platform are mostly published in English, tending to favor a greater volume of publications originating from the Global North. However, it is possible to observe that the other countries of the Global South are also trying to insert themselves into this research agenda.

Figure 5. Country/regional collaboration network on SDGs and the scientific community.

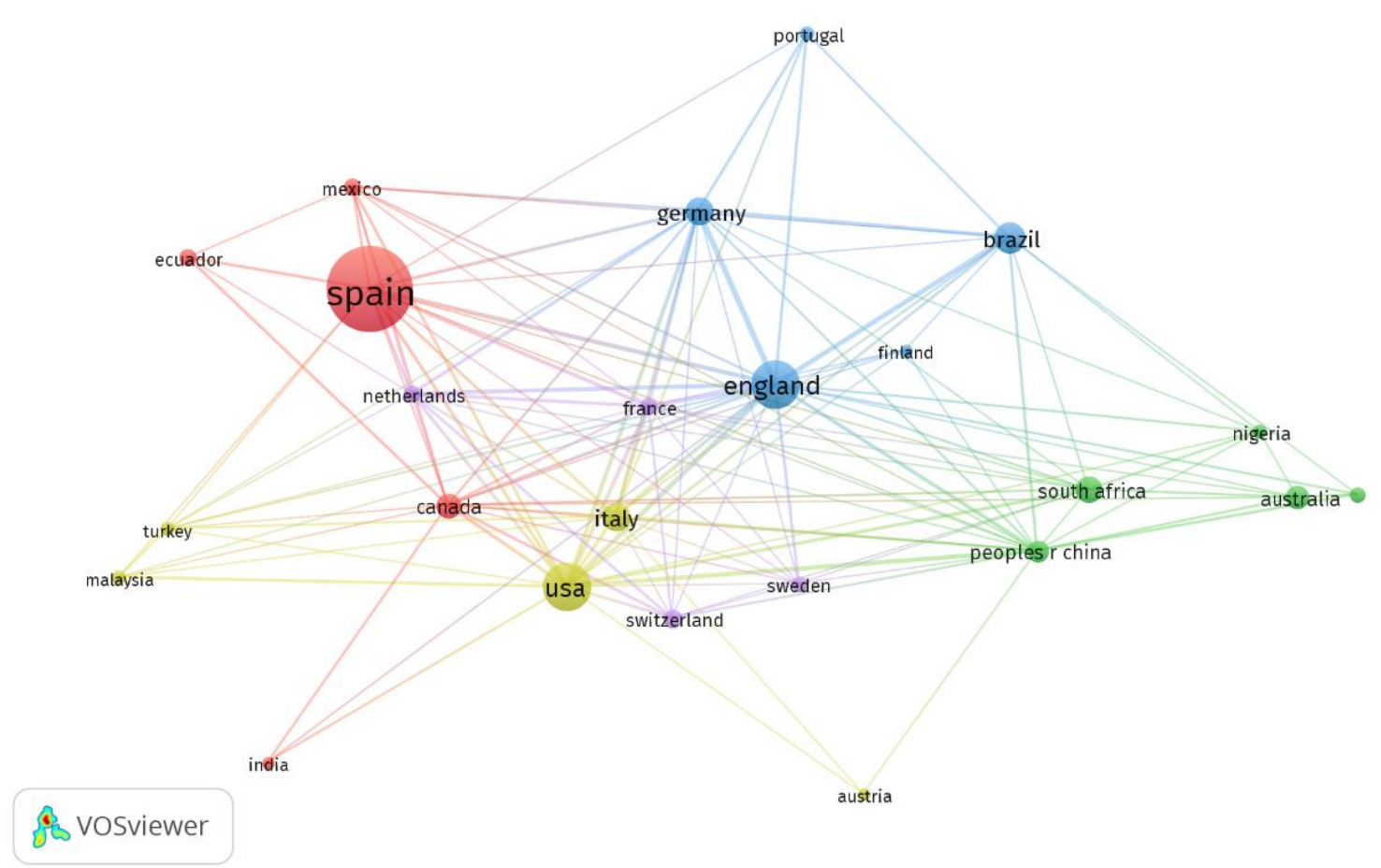

Source: Data generated from VOSviewer.

\section{Final Considerations}

Despite being a global agenda, and therefore hegemonic, the SDGs do not share an approach that seeks to transcend the prevailing capitalist production system, contradicting its goals and objectives. However, it has gained a lot of popularity worldwide and has become a mandatory requirement in certain contexts.

Within the scientific community, the SDGs demand a series of actions such as the adoption of the agenda by Higher Education Institutions and research funding agencies - beyond its contribution to the constitution of the agenda. The adoption of the SDGs in teaching, research, extension (and engagement activities with the external community), management and governance processes, as well as through the establishment of partnerships and collaborations among community players for the funding of research on the SDGs, stand out as planned activities.

To identify how this community has been collaborating with the legitimization and implementation of the SDGs, we conducted an exploratory bibliometric analysis of the scientific production indexed on the Web of Science platform (2015September/2021). In this, we identified the following: most of the studies published in the consulted period and platform originate from North-Global countries, such as Spain, England, United States and Germany; there was a quantitative growth in relation to the number of publications made in the consulted period about the SDGs and the performance of the scientific community, especially between the years 2019-2021; as the types of studies identified, case studies on experiences implemented in the university environment stand out, as well as studies that address the social commitment of this community in relation to the SDGs and studies that present research results that the scientific community can appropriate to achieve them; regarding research collaboration, there is a greater predominance among countries of the Global North, with sporadic 
collaborations between countries from the Global North-South and Global South-South; regarding the main themes identified, we highlight those related to the areas of Education, Science and Technology, and Biodiversity and Conservation.

Although the research carried out presents important results about the production of knowledge in relation to the performance of the scientific community in favor of the SDGs, it is limited due to some aspects: by using the Web of Science platform, we were able to identify articles produced in English, not corresponding to the totality of articles produced on the subject in other languages; and the search carried out is exploratory in nature, therefore, it does not correspond to the totality of studies carried out on the subject.

In this sense, providing recommendations for future research, it is encouraged that other studies be conducted with the purpose of identifying the state of the art of the incorporation of the SDGs by the scientific community in general. Some research questions are highlighted, considering the perspective of the geopolitics of knowledge and the science and technology studies: in what way have research funding agencies been incorporating this agenda? how does this differ in relation to the incorporation by Global North and Global South agencies? what are the prioritized themes in the establishment of partnerships between agencies and other stakeholders of the scientific community? in what way are these themes related to local, regional, and national problems of the institutions that incorporate them? considering local and regional databases, what is the status of research on the SDGs and the scientific community within the Global South? considering the Latin American particularities, in what way has the regional scientific community been positioning itself in relation to this agenda? and to what extent is this adoption/legitimization of the agenda not a way to guarantee research funding?.

\section{References}

Al-Jaber, M. A. \& Al-Ghamdi, S. G. (2020). Effect of virtual learning on delivering the education as part of the sustainable development goals in Qatar. Energy Reports. 6, 371-5.

Avelar, A. B. A., Da Silva-Oliveira, K. D. \& Da Silva Pereira, R. (2019). Education for advancing the implementation of the Sustainable Development Goals: A systematic approach. The international journal of management education. 17(3), 1-15.

Broo, D. G.; Boman, U. \& Törngren, M. (2021). Cyber-physical systems research and education in 2030: Scenarios and strategies. Journal of Industrial Information Integration. 21, 1-14.

Brundtland, G. H. (1987). Nosso futuro comum. Ed. FGV.

Caballero, P. (2019). The SDGs: Changing how development is understood. Global Policy. 10, 138-40.

Dibbern, T. A. \& Serafim, M. P. (2021). The mobilization of the academic community towards the SDGs: Mapping the initiatives of international scientific associations. Current Research in Environmental Sustainability. 3, 1-10.

Disterheft, A.; Caeiro, S.; Azeiteiro, U. M. \& Leal Filho, W. (2013). Sustainability science and education for sustainable development in universities: a way for transition. In: Sustainability assessment tools in higher education institutions. Springer, Cham.

Do Nascimento, E. P. (2012). Trajetória da sustentabilidade: do ambiental ao social, do social ao econômico. Estudos avançados. 26 , 51-64.

Donthu, N.; Kumar, S.; Mukherjee, D.; Pandey, N. \& Lim, W. M. (2021). How to conduct a bibliometric analysis: An overview and guidelines. Journal of Business Research. 133, 285-96.

Ellegaard, O.; Wallin, J. A. (2015). The bibliometric analysis of scholarly production: How great is the impact?. Scientometrics. 105(3), 1809-31.

European Comission. (2021). Horizon 2020. https://ec.europa.eu/programmes/horizon2020/en/home.

Fabrega, M. B; Masferrer, N.; Patau, J. \& Pérez, A. P. M. (2020). Self-counciousness competence as driver of innovation and environmental commitment in higher education students. International Journal of Sustainability in Higher Education. 21(7), 1507-23.

Fernandes, B. B. (2015). Pesquisa epidemiológica dos óbitos maternos e o cumprimento do quinto objetivo de desenvolvimento do milênio. Revista Gaúcha de Enfermagem. 36, 192-99.

Fernandez-Izquierdo, M. A.; Munoz-Torres, M. J.; Rivera-Lirio, J. M.; Ferrero-Ferrero, I.; Escrig-Olmedo, E.; Leon-Soriano, R.; Belles-Colomer, L.; GarciaPerez, I. \& Ibanez-Gallen, L. (2017). Integrating the sustainable development goals in higher education through finance subjects. 9th International Conference on Education and New Learning Technologies. Spain.

Ferraro Junior, L. A. (2016). Seeking effectiveness of the environmental agenda: beyond political reductionism. Sustainability in Debate. 7(3), 127-40. 
Freitas, R. D. C. M.; Nélsis, C. M. \& Nunes, L. S. (2012). A crítica marxista ao desenvolvimento (in) sustentável. Revista Katálysis. $15,41-51$.

Fukuda-Parr, S. (2017). Millennium development goals: ideas, interests and influence. Taylor \& Francis.

Fukuda-Parr, S.; Muchhala, B. (2020). The Southern origins of sustainable development goals: Ideas, actors, aspirations. World Development. 126,1 -11.

García-Rico, L.; Martínez-Muñoz, L. F.; Santos-Pastor, M. L. \& Chiva-Bartoll, O. (2021). Service-learning in physical education teacher education: A pedagogical model towards sustainable development goals. International Journal of Sustainability in Higher Education. 22(4), 747-65.

González-Domínguez, J.; Sánchez-Barroso, G.; Zamora-Polo, F. \& García-Sanz-Calcedo, J. (2020). Application of circular economy techniques for design and development of products through collaborative project-based learning for industrial engineer teaching. Sustainability. 12(11), 1-16.

Gore, C. (2010). The MDG paradigm, productive capacities and the future of poverty reduction. IDS bulletin. 41(1), 70-9.

GUNi. (2019). Implementing the 2030 Agenda at Higher Education Institutions: Challenges and Responses. Barcelona.

Hickel, J. (2015). Five reasons to think twice about the UN's Sustainable Development Goals. Africa at LSE, 1-4.

IIASA. (2018). Transformations to Achieve the Sustainable Development Goals. International Institute for Applied Systems Analysis (IIASA), Laxenburg, Austria.

ISC. (2020). Funding Science for Sustainability: Launch of a Decade of Global Sustainability Science Action (2020-2030). International Science Council.

ISC. (2021). Unleashing Science: Delivering Missions for Sustainability. International Science Council.

ISCN. (2018). Sustainable development: educating with purpose. http://www.guninetwork.org/files/iscn-report-2018-web.pdf.

Khan, S. R. \& Christiansen, J. (2010). Hamlet without the Prince of Denmark: how development has disappeared from today's “development” discourse. In: Towards new developmentalism. Routledge.

Kuo, W. Y.; Kim, S. H. \& Lachapelle, P. (2020). Incorporating community culture in teaching food innovation: Ideation, prototyping, and storytelling. Journal of Food Science Education. 19(4), 292-307.

Leal Filho, W.; Frankenberger, F.; Salvia, A. L.; Azeiteiro, U.; Alves, F.; Castro, P. \& Ávila, L. V. (2021). A framework for the implementation of the Sustainable Development Goals in university programmes. Journal of Cleaner Production. 299, 1-12.

Leal Filho, W.; Shiel, C.; Paço, A.; Mifsud, M.; Ávila, L. V.; Brandli, L. L. \& Caeiro, S. (2019). Sustainable development goals and sustainability teaching at universities: falling behind or getting ahead of the pack?. Journal of Cleaner Production. 232, 285-94.

Macedo, D. L.; Calazans, S.; De Souza, W. J.; Pequeno, N. P. F.; De Araujo, F. R. \& De Lima Junior, V. (2019). Integrating university extension into teaching and research in Administration: systematization of experience with indigenous people in the light of the objectives of sustainable development. Administração: Ensino e Pesquisa-RAEP. 20(3), 563-608.

Machado, V. F. (2005). A produção do discurso do desenvolvimento sustentável: de Estocolmo a Rio 92 [Tese de Doutorado, Universidade de Brasília].

Marinho, C. S. R. (2020). Objetivos de Desenvolvimento do Milênio: impacto de ações assistenciais e mudanças socioeconômicas e sanitárias na mortalidade de crianças. Cadernos de Saúde Pública. 36(10), 1-14.

Maruyama, U.; Prado, P.; Trigo, A. \& Trigo, J. (2020). Nurturing the Seeds of Sustainability Governance: Rio+ 25 Brazilian Higher Education Institution Case Study. In: Universities as Living Labs for Sustainable Development. Springer.

Meadows, D. (1972). Os limites do crescimento. São Paulo: Perspectiva.

Mibielli, P. \& Barcellos, F. C. (2014). The Millennium Development Goals (MDG): a critical evaluation. Sustainability in Debate. 5(3), $222-44$.

Moon, C.; Walmsley, A. \& Apostolopoulos, N. (2018). Sustainability and entrepreneurship education. A survey of 307 UN HESI signatories. Proceedings of the European Conference on Innovation and Entrepreneurship. Portugal.

Owojori, O.; Edokpayi, J. N.; Mulaudzi, R. \& Odiyo, J. O. (2020). Characterisation, recovery and recycling potential of solid waste in a university of a developing economy. Sustainability. 12(12), 1-17.

Perkins, K. M.; Munguia, N.; Moure-Eraso, R.; Delakowitz, B.; Giannetti, B. F.; Liu, G. \& Velazquez, L. (2018). International perspectives on the pedagogy of climate change. Journal of Cleaner Production. 200, 1043-52.

Ratiu, C. \& Anderson, B. B. (2014). The identity crisis of sustainable development. World Journal of Science, Technology and Sustainable Development. 11(1), 4-15.

Reverter, S. (2021). La igualdad de género en la universidad. Capitalismo académico y rankings globales. Investigaciones Feministas. 12(2), 271-81.

Ruíz, D. R.; Armentia, P. G. \& De La Calle Maldonado, C. (2019). Education for sustainable development: The role of the university in the 2030 agenda transformation and design of new learning environments. Prisma Social. 25, 179-202.

Ruiz-Mallén, I. \& Heras, M. (2020). What sustainability? Higher education institutions' pathways to reach the Agenda 2030 goals. Sustainability. 12(4), 1-18.

Salvia, A. L.; Brandli, L. L.; Leal Filho, W.; Rebelatto, B. G. \& Reginatto, G. (2020). Energy sustainability in teaching and outreach initiatives and the contribution to the 2030 Agenda. International Journal of Sustainability in Higher Education. 21(7), 1607-24. 
Sankowski, E. \& Harris, B. J. (2018). Is There a Crisis of Sustainable Development?. International Dialogue, A Multidisciplinary Journal of World Affairs. 8, $1-21$

Scoones, I. (2010). Sustainability. In Cornwall, A; Eade, D. (Org.). Deconstructing Development Discourses: Buzzwords and Fuzzwords. Oxfam GB.

Sugandhar, D. P. \& Chaudhary, R. (2017). Revitalize Education Opportunities through Public Private Partnerships for Achieving Sustainable Development Goals (SDGs): An Indian Experience'-'Making Partnership Central to Enabling Change'. 12th International Conference on Public Administration / 1st International Symposium on West African Studies. China.

UNESCO. (2017). Education for Sustainable Development Goals: Learning Objectives. http://www.guninetwork.org/files/247444eng.pdf.

United Nations. (1992). Report of the United Nations conference on environment and development. In: UNCED report A/Conf. l51/5rev. l. Rio de Janeiro.

United Nations. (2013). Open Working Group of the General Assembly on Sustainable Development Goals. Draft decision submitted by the President of the General Assembly. New York.

United Nations. (2014). Report of the Open Working Group of the General Assembly on Sustainable Development Goals. New York.

Vizeu, F.; Meneghetti, F. K. \& Seifert, R. E. (2012). Por uma crítica ao conceito de desenvolvimento sustentável. Cadernos EBAPE.BR. 10(3), 569-83.

Weber, J. M.; Lindenmeyer, C. P.; LIÒ, P. \& Lapkin, A. A. (2021). Teaching sustainability as complex systems approach: a sustainable development goals workshop. International Journal of Sustainability in Higher Education. 22(8), 25-41.

Xia, D. M.; Wang, X. R.; Zhou, P. Y.; Ou, T. L.; Su, L. \& Xu, S. G. (2021). Research progress of heat stroke during 1989-2019: a bibliometric analysis. Military Medical Research. 8(1), 1-11. 